\title{
Comparative leukocyte morphometric analysis between endemic Anurans from Brazil and the invasive species Lithobates catesbeianus
}

\author{
Análise morfométrica comparada entre Anuros endêmicos \\ do Brasil e a espécie invasora Lithobates catesbeianus
}

\author{
Stephanie Moira Rodrigues e SILVA'; Ana Carolina EWBANK'; Ricardo de Francisco STREFEZZI²; \\ Gilbert ALVARADO ${ }^{1}$; Carlos SACRISTAN ${ }^{1}$; Cátia Dejuste de PAULA ${ }^{1,3}$; José Luiz CATÃO-DIAS ${ }^{1}$ \\ ${ }^{1}$ Universidade de São Paulo, Faculdade de Medicina Veterinária e Zootecnia, Departamento de Patologia, \\ Laboratório de Patologia Comparada, São Paulo - SP, Brazil \\ ${ }^{2}$ Universidade de São Paulo, Faculdade de Zootecnia e Engenharia de Alimentos, Departamento de Medicina Veterinária, \\ Laboratório de Oncologia Comparada e Translacional, Pirassununga - SP, Brazil \\ ${ }^{3}$ Instituto Brasileiro para Medicina da Conservação, Recife - PE, Brazil
}

\begin{abstract}
Amphibians are potentially reliable and efficient bioindicators. Existing anuran white blood cell morphology studies are limited, with only a few morphometric studies available. We employed morphometric techniques to characterize leukocytes of selected Neotropical anurans from Brazil and compare our findings with the exotic American Bullfrog (Lithobates catesbeianus), genus Ranidae. We compared blood smears of 28 specimens from six different genera (Hyla, Phyllomedusa, Hypsiboas, Scinax, Physalaemus, and Proceratophrys) with samples from L. catesbeianus. Leukocyte average diameter was calculated by an image analysis software. One-way analyses of variance and Bonferroni tests were used on statistical analyses. Lymphocytes, neutrophils, eosinophils, and basophils were significantly smaller than the reference ranges reported for other amphibian genera, including Lithobathes, whereas monocyte diameters did not differ significantly between genera. This is the first study to evaluate leukocyte morphometrics of Brazilian anuran species. Our findings suggest that geographical separation could possibly influence leukocyte morphometry.
\end{abstract}

Keywords: Anura. Morphometry. South America. White blood cells.

\section{Resumo}

Anfíbios são indicadores ambientais potencialmente confiáveis e eficientes. Estudos referentes à morfologia deleucócitos de anuros são limitados, com poucos estudos morfométricos disponíveis em literatura. O presente estudo empregou técnicas morfométricas para caracterizar leucócitos de anuros Neotropicais brasileiros selecionados e compará-los com a espécie exótica rã-touro (Lithobates catesbeianus), família Ranidae. Esfregaços sanguíneos de 28 espécimes pertencentes a seis gêneros diferentes (Hyla, Phyllomedusa, Hypsiboas, Scinax, Physalaemus e Proceratophrys) foram comparados com amostras de esfregaços de L. catesbeianus. A média do diâmetro dos leucócitos foi calculada por um software de análise de imagens. One-way e teste de Bonferroni foram utilizados para avaliação estatística. Linfócitos, neutrófilos, eosinófilos e basófilos mostraram-se significativamente menores que os valores de referência reportados em outros gêneros de anfíbios, incluindo Lithobathes; por outro lado, a média do diâmetro dos monócitos não demonstrou variação significativa entre os gêneros. Esse é o primeiro estudo de avaliação morfométrica de leucócitos em espécies de anuros brasileiros. Nossos resultados sugerem que a separação geográfica possivelmente influencia a morfometria leucocitária.

Palavras-chave: Anura. Morfometria. América do Sul. Leucócitos. 
Correspondence to:

Ana Carolina Ewbank

Universidade de São Paulo, Faculdade de Medicina Veterinária

e Zootecnia, Departamento de Patologia, Laboratório de

Patologia Comparada

Av. Professor Orlando Marques de Paiva, 87

CEP 05508-270, São Paulo, SP, Brazil

e-mail: carolewbank@yahoo.com.br

Received: 12/10/2016

Approved: 03/05/2017

\section{Introduction}

Amphibians often correspond to a significant proportion of the vertebrate biomass in forest and wetland ecosystems (HAMER;MCDONNELL, 2008), therefore being potentially reliable and efficient bioindicators (GÜL; TOSUNOĞLU; ERDOĞAN, 2011; MAHAPATRA et al., 2012; ZHELEV et al., 2013), very sensitive to the slightest fluctuations in their habitat (GÜL; TOSUNOĞLU; ERDOĞAN, 2011; MAHAPATRA et al., 2012).

The hematopoietic tissue is particularly sensitive to environmental changes and is an important indicator of physiological response and stress agents, which are quickly reflected in hematologic parameters (ALLENDER; FRY, 2008; DAVIS; MANEY; MAERZ , 2008; SHUTLER; MARCOGLIESE, 2011). Hematologic and biochemical evaluation of amphibians is of great clinical importance, and provides valuable diagnostic information and understanding of the pathogenesis of diseases, their progression, and response to therapy (SCHMID-SCHÖNBEIN et al., 1980; ALLENDER; FRY, 2008; DAVIS; DURSO, 2009; YOUNG et al., 2012). Nevertheless, there are few studies available on Neotropical amphibian hematology (CABAGNAZENKLUSEN et al., 2005; CABAGNA-ZENKLUSEN et al., 2011; LAJMANOVÍCH et al., 2012), and scarce studies on anuran white blood cell morphology (ARIKAN; ÇIÇEK, 2010; DAS; MAHAPATRA, 2012). Few morphometric studies of red blood cells (BARNI et al., 1992; ATATÜR et al., 1999; WOJTASZEK; ADAMOWICZ, 2003; GRENAT et al., 2009) and white blood cells (FOXON 1964; NANO et al., 1991; TOZETTI et al., 2014) are available. To the authors' knowledge, this is the first study on white blood cell morphology in Neotropical anurans from South America.

We employed morphometric techniques to characterize leukocytes of selected Neotropical anurans from Brazil. We also compared our findings with an exotic species of the same order: the American Bullfrog (Rana catesbeiana), genus Ranidae, recently named Lithobates catesbeianus (FROST et al., 2006).

\section{Materials and Methods}

\section{Sample Collection and Processing}

Because of technical restrictions, we evaluated 28 out of 55 free-ranging animals collected at Chapada Diamantina National Park, in the state of Bahia, Brazil. All animals were individually placed in labeled plastic bags that allowed free air exchange, over a substrate of leaves and a small amount of water to mimic their natural habitat. Bags were placed in a quiet and temperature-controlled environment in order to minimize stress, until the administration of topical lidocaine (Xylocaína 5\%, AstraZeneca do Brasil. Cotia, SP, Brazil). Sample collection and humane euthanasia were performed only after the animals were anesthetized and unconscious.

Blood sampling through cardiocentesis avoided sampling limitations related to the small size of the individuals and reduced the amount of circulating blood. Each animal was placed on dorsal recumbence while the cardiac pulse could still be clearly discerned. Blood samples were immediately collected with a disposable $25 \mathrm{G} \mathrm{x} \mathrm{5/8}$ in. needle, inserted in the direction of the ventricular apex. Insulin needles were used in the smaller species. A single drop of blood was placed on the edge of a slide, and equally distributed by a spreader slide angled at $45^{\circ}$. The coelomic cavity was incised immediately after anesthetic absorption and cessation of cardiac contractions in those species considered too small for cardiocentesis. The whole heart was excised, sectioned and slid on the slide surface, so the blood cells present in the tissue section could be visualized. Slides were stained with Rosenfeld stain using an adapted protocol version based on Rosenfeld (1947).

Weanalyzedblood smears from 28 Neotropical specimens, from six different genera: Hyla $(n=7)$, Phyllomedusa $(n=5)$, Hypsiboas $(n=5)$, Scinax $(n=4)$, Physalaemus $(n=4)$, and Proceratophrys $(n=3)$. To enable the comparison between the Brazilian and North American species, we included blood smears of Lithobates catesbeianus $(n=6)$.

All animals used in this study were collected in full compliance with specific federal permits issued by the Brazilian Ministry of Environment and approved by the Biodiversity Information and Authorization System SISBIO, License $\mathrm{n}^{\circ} 14555-2$, to be incorporated into the collection of the Museum of Zoology, University of São Paulo (MZUSP). All procedures were performed according to the Ethical Committee in Animal Research of the College of Veterinary Medicine and Animal Sciences, University of São Paulo (Proccess number 1686/2009). 


\section{Slide Interpretation}

Leukocytes were analyzed and counted under 100x magnification and immersion oil. We identified and documented the following blood cell types: neutrophils, eosinophils, basophils, monocytes, and lymphocytes. Leukocytes were identified and evaluated according to previous authors (WRIGHT 1996; CATHERS et al., 1997; DAVIS; DURSO, 2009; HEATLEY; JOHNSON, 2009). Thrombocytes and erythrocytes were not included in this study.

\section{Cell Measurement and Data Analysis}

Blood smears were observed under a microscope equipped with a digital camera and connected to a computer with image analysis software (Image ProPlus, v 5.1.2.59 Media Cybernetics, Inc., Bethesda, MD). The whole slide was examined and all visualized leukocytes were individually analyzed and manually outlined to determine the cell average diameter (in $\mu \mathrm{m}$, equivalent to the mean measurement of the diameters measured at 5 intervals around the center of the cell). We chose this technique because of the small size of some of the evaluated specimens and consequently small blood volume available for analysis.

Statistical analysis was performed by One-way analysis of variance followed by Bonferroni tests, with the significance level set at 5\%. Data were analyzed with
GraphPad Prism (Prism 4.02 for Windows, GraphPad Software Inc.).

\section{Results}

Lymphocytes were basophilic, showed round nuclei with dense chromatin aggregates and scarce cytoplasm with frequent cytoplasmic "pseudopods". Lymphocytes of the Scinax genus were significantly smaller than the ones from Hyla, Phyllomedusa $(P<0.05)$, and Lithobathes $(P<0.01)$ genera. Hypsiboas lymphocytes were also smaller than Lithobathes $(P<0.05)$, but no differences were found in relation to Scinax (Figure 1a; Table 1).

The majority of amphibian neutrophils had lobulated nuclei. Neutrophils of the Scinax genus were significantly smaller than the ones from the Hyla $(P<0.01)$, Phyllomedusa $(P<0.05)$ and Lithobathes $(P<0.05)$ genera. (Figure $1 \mathrm{~b}$; Table 1). Physalaemus neutrophils were also smaller than Hyla, Phyllomedusa $(P<0.01)$, and Lithobathes $(P<0.05)$, but no differences were found between Scinax and Physalaemus.

Eosinophils were similar to neutrophils, but presented big, refringent, and eosinophilic intracytoplasmic granules. Eosinophils of the Scinax $(P<0.01)$ and Physalaemus $(P<0.05)$ genera were significantly smaller than the ones from Lithobathes genus. Proceratophrys neutrophils were smaller than Hyla $(P<0.01)$ and Lithobathes $(P<0.001)$ (Figure 1c; Table 1).

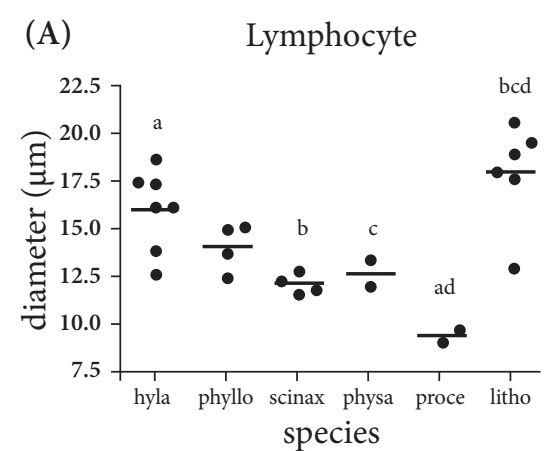

(D)

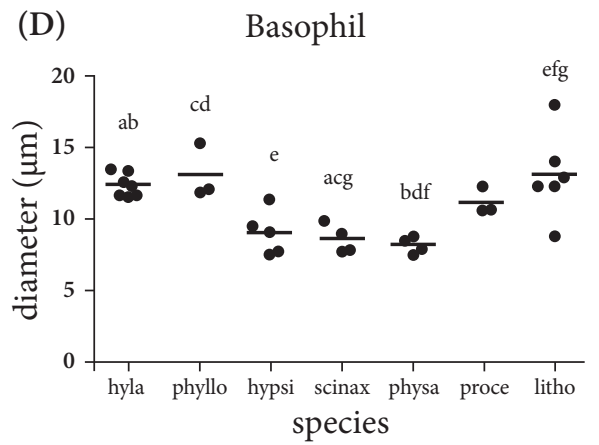

(B) Neutrophil

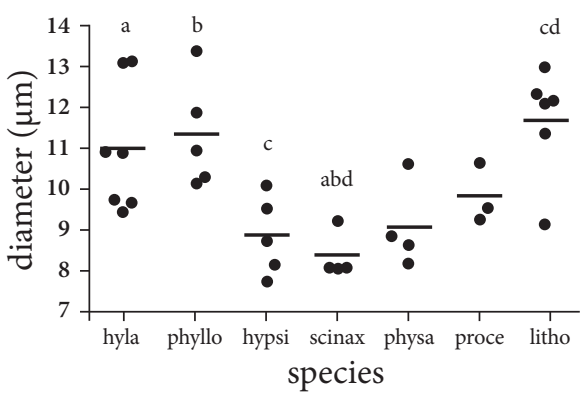

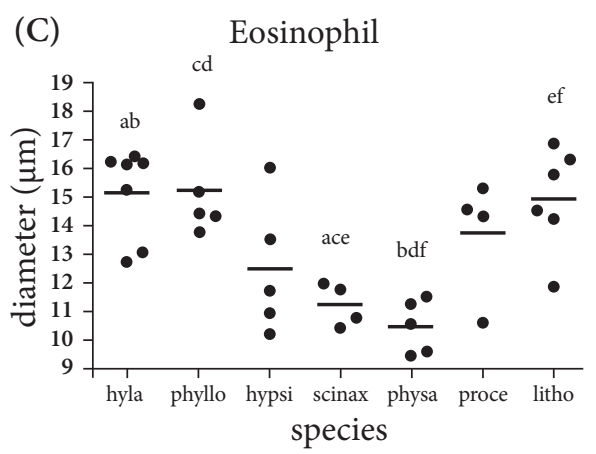

(E) Monocyte

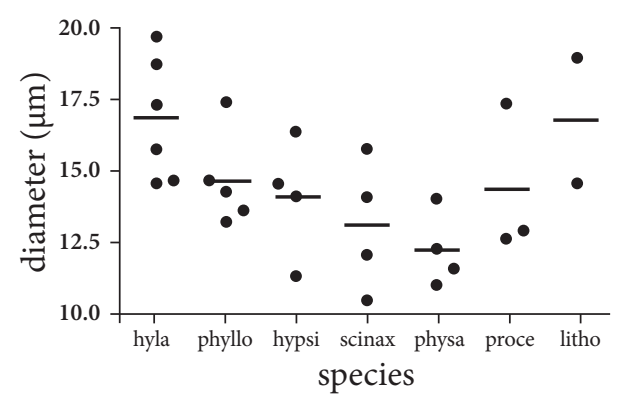

Figure 1 - Leukocyte diameter values for the analyzed species: (a) Lymphocytes, (b) Neutrophils, (c) Eosinophils, (d) Basophils, and (e) Monocytes 
Table 1 - Leukocyte diameter values for the analyzed genera and species - São Paulo - October 11, 2016

\begin{tabular}{|c|c|c|c|c|c|c|}
\hline Genus & Parameters & Lymphocytes & Neutrophils & Eosinophils & Basophils & Monocytes \\
\hline Hyla & $\begin{array}{l}\text { Mean } \pm \text { SD } \\
\text { Max - Min }\end{array}$ & $\begin{array}{l}10.98 \pm 1.60^{a} \\
(9.39-13.16)\end{array}$ & $\begin{array}{c}15.16 \pm 1.58^{\mathrm{ab}} \\
(12.73-16.43)\end{array}$ & $\begin{array}{c}16.05 \pm 2.13^{\mathrm{a}} \\
(12.66-18.65)\end{array}$ & $\begin{array}{c}12.37 \pm 0.80^{\mathrm{ab}} \\
(11.59-13.44)\end{array}$ & $\begin{array}{c}16.78 \pm 2.16 \\
(14.55-19.70)\end{array}$ \\
\hline Phyllomedusa & $\begin{array}{l}\text { Mean } \pm \text { SD } \\
\text { Max }- \text { Min }\end{array}$ & $\begin{array}{l}11.33 \pm 1.35^{b} \\
(10.14-13.4)\end{array}$ & $\begin{array}{c}15.20 \pm 1.78^{\mathrm{cd}} \\
(13.78-18.23)\end{array}$ & $\begin{array}{c}14.05 \pm 1.25 \\
(12.44-15.11)\end{array}$ & $\begin{array}{c}13.09 \pm 2.00^{c d} \\
(11.83-15.40)\end{array}$ & $\begin{array}{c}14.60 \pm 1.65 \\
(13.18-17.37)\end{array}$ \\
\hline Hypsiboas & $\begin{array}{l}\text { Mean } \pm \text { SD } \\
\text { Mean } \pm \text { SD }\end{array}$ & $\begin{array}{c}8.82 \pm 0.99^{c} \\
(7.69-10.08)\end{array}$ & $\begin{array}{c}12.50 \pm 2.33 \\
(10.23-16.04)\end{array}$ & - & $\begin{array}{c}9.00 \pm 1.60^{\mathrm{e}} \\
(7.42-11.39)\end{array}$ & $\begin{array}{c}14.05 \pm 2.08 \\
(11.29-16.32)\end{array}$ \\
\hline Scinax & $\begin{array}{l}\text { Max }- \text { Min } \\
\text { Mean } \pm \text { SD }\end{array}$ & $\begin{array}{c}8.33 \pm 0.59^{\mathrm{abd}} \\
(8.02-9.20)\end{array}$ & $\begin{array}{c}11.25 \pm 0.74^{\text {ace }} \\
(10.46-11.97)\end{array}$ & $\begin{array}{c}12.12 \pm 0.52^{b} \\
(11.60-12.79)\end{array}$ & $\begin{array}{l}8.56 \pm 1.06^{\mathrm{acf}} \\
(7.65-9.85)\end{array}$ & $\begin{array}{c}13.04 \pm 2.31 \\
(10.42-15.71)\end{array}$ \\
\hline Physalaemus & $\begin{array}{l}\text { Max }- \text { Min } \\
\text { Mean } \pm \text { SD }\end{array}$ & $\begin{array}{c}9.04 \pm 1.07 \\
(8.16-10.59)\end{array}$ & $\begin{array}{c}10.51 \pm 0.92^{\mathrm{bdf}} \\
(9.49-11.53)\end{array}$ & $\begin{array}{c}12.68 \pm 1.00^{c} \\
(11.97-13.39)\end{array}$ & $\begin{array}{c}8.14 \pm 0.61^{b d g} \\
(7.44-8.77)\end{array}$ & $\begin{array}{c}12.19 \pm 1.31 \\
(10.99-14.00)\end{array}$ \\
\hline Proceratophrys & $\begin{array}{l}\text { Max - Min } \\
\text { Mean } \pm \text { SD }\end{array}$ & $\begin{array}{c}9.79 \pm 0.76 \\
(9.23-10.64)\end{array}$ & $\begin{array}{c}13.72 \pm 2.09 \\
(10.64-15.30)\end{array}$ & $\begin{array}{l}9.40 \pm 0.44^{\mathrm{ad}} \\
(9.08-9.71)\end{array}$ & $\begin{array}{c}11.18 \pm 0.98 \\
(10.57-12.30)\end{array}$ & $\begin{array}{c}14.27 \pm 2.67 \\
(12.60-17.35)\end{array}$ \\
\hline L. catesbeianus & $\begin{array}{l}\text { Mean } \pm \text { SD } \\
\text { Max - Min }\end{array}$ & $\begin{array}{l}11.69 \pm 1.37^{c d} \\
(9.13-13.02)\end{array}$ & $\begin{array}{c}14.95 \pm 1.81^{e f} \\
(11.90-16.88)\end{array}$ & $\begin{array}{l}17.94 \pm 2.68^{\mathrm{bcd}} \\
(12.96-20.62)\end{array}$ & $\begin{array}{l}13.03 \pm 3.01^{\mathrm{efg}} \\
(8.78-18.03)\end{array}$ & $\begin{array}{c}16.73 \pm 3.14 \\
(14.51-18.95)\end{array}$ \\
\hline
\end{tabular}

Similar letters indicate significant differences. No eosinophils were observed in the Hypsiboas genus

Basophils were round-shaped and in some cases elliptical, presenting well delimitated and numerous intense basophilic granules that prevented the observation of the nucleus. The outlining of the cell followed the granules adhered to the cytoplasmic membrane. Basophils of the Scinax genus were significantly smaller than the ones from the Hyla $(P<0.05)$, Phyllomedusa $(P<0.05)$, and Lithobathes $(P<0.01)$ genera. Basophils of the Physalaemus genus were significantly smaller than the ones from the Hyla $(P<0.05)$, Phyllomedusa $(P<0.05)$, and Lithobathes $(P<0.01)$ genera. Moreover, basophils of the Hypsiboas genus were significantly smaller than those from the Lithobathes genus $(P<0.05)$. No differences were found between Proceratophrys and any of the other evaluated genera (Figure 1d; Table 1).

In this study, the monocytes studied were horseshoeor kidney-shaped, presenting eccentric nuclei. Monocyte diameters varied from 10.42 to $19.70 \mu \mathrm{m}$, but no significant differences were found between genera (Figure 1e; Table 1).

\section{Discussion}

Amphibians have suffered massive, widespread, often unexplained, and probably irreversible decline of population worldwide over the last several decades. Among the world's vertebrates, amphibians present the highest proportion of species on the verge of extinction (HAMER; MCDONNELL, 2008), with thousands of species with diminished population and hundreds on the brink of extinction or already vanished (STUART et al., 2004; POUNDS et al., 2006). Since 1980, between 9 and 122 species have been considered "possibly extinct" (STUART et al., 2004).
The amphibian population decline phenomenon is complex in origin and multifactorial in etiology, caused by some of the following identified causes: habitat loss and overutilization, fragmentation, degradation, pathogens, pollution, introduced exotic species, climate change and associated atmospheric processes, and overexploitation, including collection for pet and food industries (STUART et al., 2004; POUNDS et al., 2006; HAMER; MCDONNELL, 2008; BLAUSTEIN et al., 2011). Declines in population are nonrandom in terms of species' ecological preferences, geographic ranges, and taxonomic associations, probably varying between species, populations, and life stages within a population, and most prevalent in Neotropical mountainous stream-associated species (STUART et al., 2004; BLAUSTEIN et al., 2011).

According to the latest update of the List of Brazilian Amphibians (July 2014) there are 1026 recognized amphibian species in Brazil: 988 Anurans, 5 Caudatas, and 33 Gymnophionas (SEGALLA et al., 2014). However, the information about these species is scarce, and the accelerated global amphibian decline indicates the need to rapidly expand conservation research programs and emergency strategies (SILVANO; SEGALLA, 2014).

Blood analyses are useful in the diagnosis and monitoring of animal health and disease and in the differentiation of physiological processes (ARIKAN; ÇIÇEK, 2010). In environmentally sensitive animals such as anurans, variation in white blood cell parameters is also an indicator of environmental stress (DAS; MAHAPATRA, 2012). However, amphibian hematology is specially challenging because of a combination of several factors: 
lack of analytical methods, challenges to sample collection (small size, few venipuncture sites, sample volume restrictions, and contamination of blood with lymph), and the variability in amphibian red blood cell (RBC) and white blood cell (WBC) counts (ALLENDER; FRY, 2008; ARIKAN et al., 2010; GÜL; Tosunoğlu; Erdoğan, 2011; MAHAPATRA et al., 2012).

Native to the eastern United States and Canada (GIOVANELLI et al., 2008; BOTH et al., 2011), L. catesbeianus was introduced in Brazil in the 1930s, in association with aquaculture (GIOVANELLI et al., 2008; ROCHA et al., 2010). L. catesbeianus was included in this study because of its economical importance and the variety of hematologic studies of this species available (CATHERS et al., 1997; COPPO et al., 2005; DAVIS, 2009; ROCHA et al., 2010).

Lymphocytes were by far the most frequently observed leukocyte in the evaluated species and genera, as previously reported in other amphibian species (ARSERIM; MERMER, 2008; ARIKAN et al., 2010; ARIKAN; ÇIÇEK, 2010; DAS; MAHAPATRA, 2012). The lymphocyte morphology observed in this study is consistent with descriptions by other authors (ARSERIM; MERMER, 2008; ARIKAN et al., 2010; CAMPBELL 2012; DAS; MAHAPATRA, 2012). We also observed different lymphocyte sizes (large and small), as previously described (WRIGHT, 1996; ARSERIM; MERMER, 2008; ARIKAN et al., 2010; ARIKAN; ÇIÇEK, 2010), but in order to simplify our correlations, we decided to classify these cells only as "lymphocytes", instead of identifying them according to size. In amphibians, the lymphocyte diameter varies between 10 and $25 \mu \mathrm{m}$ in most species (WRIGHT, 1996; HEATLEY; JOHNSON, 2009; ARIKAN et al., 2010; CAMPBELL, 2012). The mean lymphocyte diameters of Scinax and Hypsiboas genera ( $8.33 \pm 0.59$ and $8.82 \pm 0.99 \mu \mathrm{m}$, respectively) were similar to those of balloon frogs (Glyphogloossus molossus, $8.56 \pm 2.74 \mu \mathrm{m}$, range $7.74-11.30 \mu \mathrm{m}$ ) (SINSCH, 1990).

Monocyte morphology reported in this study is in agreement with previous reports (ARSERIM; MERMER, 2008; ARIKAN; ÇIÇEK, 2010; OMONONA; EKPENKO, 2011; CAMPBELL, 2012). The mean monocyte diameters found for Hypsiboas (14.06 $\pm 2.09 \mu \mathrm{m})$, Phyllomedusa $(14.60 \pm 1.66 \mu \mathrm{m})$, and especially for Proceratophrys $(14.27 \pm 2.67 \mu \mathrm{m})$, were comparable to those found for Long-legged wood frog (Rana macrocnemis, $14.30 \pm 0.19$ $\mu \mathrm{m}$, range $10.00-18.50 \mu \mathrm{m}$ ) (ARSERIM; MERMER, 2008), and the ones found for Scinax $(13.05 \pm 2.32 \mu \mathrm{m})$ were comparable to those of G. molossus (13.89 \pm 3.34 $\mu \mathrm{m})$ (PONSEN et al., 2008). As with other vertebrates, monocytes are phagocytic and can migrate to tissues to turn into macrophages. Apart from directly eliminating pathogens, monocytes and macrophages can process certain antigens and stimulate lymphocyte production (DAVIS; DURSO, 2009; CAMPBELL, 2012). Monocytes showed eccentric, horseshoe- or kidney-shaped nuclei, as reported by previous authors (ARSERIM; MERMER, 2008; ARIKAN; ÇIÇEK, 2010; OMONONA; EKPENKO, 2011; CAMPBELL, 2012).

Granulocytes include neutrophils, eosinophils, and basophils. Neutrophils are usually round-shaped, and may be defined as "small eosinophilic granulated lymphocytes", with a typical elongated shape (WRIGHT, 1996). The majority of amphibian neutrophils presented lobulated nuclei, but Allender and Fry (2008) have reported clinically normal amphibians with hyposegmented nuclei. Neutrophil morphology is in agreement with the literature (ARIKAN et al., 2010; ARIKAN; ÇIÇEK, 2010; DAS; MAHAPATRA, 2012; MAHAPATRA et al., 2012). Neutrophil diameters found for Hyla (15.24 $\pm 1.65 \mu \mathrm{m})$ and Phyllomedusa (15.19 $\pm 1.77 \mu \mathrm{m}$ ) were similar to those found for L. catesbeianus by Coppo et al. (2005) $(15.2 \pm 2.1 \mu \mathrm{m}$, range $11.3-20.5$ $\mu \mathrm{m})$, but not to the values for $L$. catesbeianus $(17.93 \pm 2.67$ $\mu \mathrm{m})$ found in the present study.

Eosinophil and basophil descriptions are in agreement with previous authors (ARSERIM; MERMER, 2008; ARIKAN et al., 2010; ARIKAN; ÇIÇEK, 2010). The eosinophil diameter found for Hyla $(16.06 \pm 2.13 \mu \mathrm{m})$ was comparable to those found for $R$. macrocnemis $(16.30 \pm 0.21 \mu \mathrm{m}$, range $11.75-19.75 \mu \mathrm{m})$ (ARSERIM: MERMER, 2008), fire-bellied toad (Bombina bombina, $16.40 \pm 1.026 \mu \mathrm{m}$, range $15-18.5 \mu \mathrm{m}$ ) (ARIKAN et al., 2010), and L. catesbeianus (16.2 $\pm 2.5 \mu \mathrm{m}$, range 11.3 $21.5 \mu \mathrm{m})$ (COPPO et al., 2005). However, L. catesbeianus' eosinophils were smaller in our study $(14.94 \pm 1.80 \mu \mathrm{m})$. Regarding basophils, Phyllomedusa $(13.10 \pm 2.00 \mu \mathrm{m})$ and Lithobathes $(13.03 \pm 3.02 \mu \mathrm{m})$ mean diameter values were comparable to those found in $R$. macrocnemis (13.69 \pm $0.15 \mu \mathrm{m}$, range $10.50-16.25 \mu \mathrm{m}$ ) (ARSERIM; MERMER, 2008). As in other species, basophils may fulfill a role in surveillance and eosinophil recruiting on the event of a helminthic infection (WRIGHT, 1996; YOUNG et al., 2012). Degranulated basophils can also be identified in the bloodstream (ALLENDER; FRY, 2008), being relatively common in some species (YOUNG et al., 2012). 


\section{Conclusion}

This study compared the mean diameters of leukocytes (neutrophils, basophils, eosinophils, lymphocytes, and monocytes) of six different amphibian genera within the anuran order native of Chapada Diamantina (South America), and the exotic North American species $L$. catesbeianus, showing significant differences in leukocyte morphometry. We initially expected some similarities in blood cell morphometry amongst the South American genera and significant differences with the North American genus. However, the South American genera presented few morphometric similarities, as shown in table 1. Our results suggest that the geographical separation between the North American genus and the six South American genera could possibly have influenced a certain differentiation in leukocyte morphometry, once the migratory behavior of anuran amphibians consists of short-distance or microgeographic dislocations, generally not longer than
$1500 \mathrm{~m}$, and site fidelity to these spatial units (SINSCH, 1990; RUSSELL et al., 2005). Further research in the field of amphibian hematology is needed to better characterize the Brazilian species. To the authors' knowledge, this is the first study to evaluate leukocyte morphology of Brazilian anuran species. We hope our results may contribute as a general reference and stimulate future leukocyte morphology and morphometric investigations involving anuran species from the Brazilian caatinga and Lithobathes.

\section{Acknowledgments}

We thank J. Oyakawa, at Faculdade de Medicina Veterinária e Zootecnia, Universidade de São Paulo, for his technical support and collaboration. This work was supported by the Coordination for the Improvement of Higher Level Personnel (CAPES) and by the National Counsel of Technological and Scientific Development (CNPQ) (grant number 138966/2010-9).

\section{References}

ALLENDER, M. C.; FRY, M. M. Amphibian hematology. Veterinary Clinics of North America: Exotic Animal Practice, v. 11, n. 3, p. 463-480, 2008. doi: 10.1016/j.cvex.2008.03.006.

ARIKAN, H.; ALPAGUT-KESKIN, N.; ÇEVIK, İ. E.; ERIŞMIŞ, U.C. A study on the blood cells of the fire-bellied toad, Bombina bombina L. (Anura: Bombinatoridae). Animal Biology, v. 60, n. 1, p. 61-68, 2010. doi: 10.1163/1 $57075610 X 12610595764174$.

ArIkan, H.; Çiçek, K. Morphology of peripheral blood cells from various species of Turkish Herpetofauna. Acta Herpetologica, v. 5, n. 2, p. 179-198, 2010. doi: 10.13128/ Acta_Herpetol-8526.

ARSERIM, S. K.; MERMER, A. Hematology of the Uludağ Frog, Rana macrocnemis Boulenger, 1885 in Uludağ National Park (Bursa, Turkey). Su Ürünleri Dergisi, v. 25, p. 39-46, 2008.

ATATÜR, M. K.; ARIKAN, H.; ÇEVİK, I. E. Erythrocyte sizes of some anurans from Turkey. Turkish Journal of Zoology, v. 23, n. 2, p. 111-114, 1999.

BARNI, S.; NANO, R.; BERTONE, V.; PROSPERI, E. Ultrastructure and cytochemistry of circulating erythrocytes during the annual cycle of Rana esculenta L. Comparative Haematology International, v. 2, n. 3, p. 166-169, 1992. doi: 10.1007/BF00426172.

BLAUSTEIN, A. R.; HAN, B. A.; RELYEA, R. A.; JOHNSON, P. T.; BUCK, J. C.; GERVASI, S. S.; KATS, L. B. The complexity of amphibian population declines: understanding the role of cofactors in driving amphibian losses. Annals of the New York Academy of Sciences, v. 1223, n. 1, p. 108-119, 2011. doi: 10.1111/j.17496632.2010.05909.x.

BOTH, C.; LINGNAU, R.; SANTOS JUNIOR, A.; MADALOZZO, B.; LIMA, L. P.; GRANT, T. Widespread occurrence of the American bullfrog, Lithobates catesbeianus (Shaw, 1802) (Anura: Ranidae), in Brazil. South American Journal of Herpetology, v. 6, n. 2, p. 127-134, 2011. doi: 10.2994/057.006.0203.

CABAGNA-ZENKLUSEN, M.; LAJMANOVÍCH, R. C.; ATTADEMO, A. M.; PELTZER, P. M.; JUNGES, C. M.; FIORENZA BIANCUCCI, G.; BASSÓ, A. Hematología y citoquímica de las células sanguíneas de Rhinella fernandezae (Anura: Bufonidae) en Espinal y Delta-Islas del río Paraná, Argentina. Revista de Biología Tropical, v. 59, n. 1, p. 17-28, 2011. doi: 10.15517/rbt.v59i1.3175. 
CABAGNA-ZENKLUSEN, M.; LAJMANOVÍCH, R. C.; STRINGHINI, G.; SANCHEZ-HERNANDEZ, J. C.; PELTZER, P. M. Hematological parameters of health status in the common toad Bufo arenarum in agroecosystems of Santa Fe Province, Argentina. Applied Herpetology, v. 2, n. 4, p. 373-380, 2005. doi: 10.1163/157075405774483085.

CAMPBELL, T. W. HEMATOLOGY OF AMPHIBIANS. IN: THRALL, M. A.; WEISER, G.; ALLISON, R.; CAMPBELL, T. W. Veterinary hematology and clinical chemistry. Hoboken: Wiley-Blackwell, 2012. p. 313-320.

CATHERS, T.; LEWBART, G. A.; CORREA, M.; STEVENS, J. B. Serum chemistry and hematology values for anesthetized American bullfrogs (Rana catesbeiana). Journal of Zoo and Wildlife Medicine, v. 28, n. 2, p. 171174, 1997.

COPPO, J. A.; MUSSART, N. B.; FIORANELLI, S. A.; ZEINSTEGER, P. A. Blood and urine physiological values in captive bullfrog, Rana catesbeiana (Anura: Ranidae). Analecta Veterinaria, v. 53, n. 3-4, p. 15-17, 2005. doi: 10.15517/rbt.v53i3-4.14669.

DAS, M.; MAHAPATRA, P. K. Blood cell profiles of the tadpoles of the Dubois's tree frog, Polypedates teraiensis Dubois, 1986 (Anura: Rhacophoridae). The Scientific World Journal, v. 2012, e701746, p. 1-11, 2012. doi: 10.1100/2012/701746.

DAVIS, A. K. Metamorphosis-related changes in leukocyte profiles of larval bullfrogs (Rana catesbeiana). Comparative Clinical Pathology, v. 18, n. 2, p. 181-186, 2009. doi: 10.1007/s00580-008-0773-8.

DAVIS, A. K.; DURSO, A. M. White blood cell differentials of northern cricket frogs (Acris c. crepitans) with a compilation of published values from other amphibians. Herpetologica, v. 65, n. 3, p. 260-267, 2009. doi: 10.1655/08052R1.1.

DAVIS, A. K.; MANEY, D. L.; MAERZ, J. C. The use of leukocyte profiles to measure stress in vertebrates: a review for ecologists. Functional Ecology, v. 22, n. 5, p. 760-772, 2008. doi: 10.1111/j.1365-2435.2008.01467.x.
FOXON, G. E. H. Blood and respiration. In: Moore, J. A. Physiology of the Amphibia. New York: Academic Press, 1964. p. 151-209.

FROST, D. R.; GRANT, T.; FAIVOVICH, J.; BAIN, R. H.; HAAS, A.; HADDAD, C. F. B.; DE SA, R. O.; CHANNING, A.; WILKINSON, M.; DONNELLAN, S. C.; RAXWORTHY, C. J.; CAMPBELL, J. A.; BLOTTO, B. L.; MOLER P.; DREWES, R. C.; NUSSBAUM, R. A.; LYNCH, J. D.; GREEN, D. M.; WHEELER, W. C. The amphibian tree of life. Bulletin of the American Museum of Natural History, v. 297, p. 1-370, 2006. doi: 10.1206/0003-0090(2006)297[0001:TATOL]2.0.CO;2.

GIOVANELLI, J. G.; HADDAD, C. F.; ALEXANDRINO, J. Predicting the potential distribution of the alien invasive American bullfrog (Lithobates catesbeianus) in Brazil. Biological Invasions, v. 10, n. 5, p. 585-590, 2008. doi: 10.1007/s10530-007-9154-5.

GRENAT, P. R.; BIONDA, C.; SALAS, N. E.; MARTINO, A. L. Variation in erythrocyte size between juveniles and adults of Odontophrynus americanus. Amphibia-Reptilia, v. 30, n. 1, p. 141-145, 2009. doi: $10.1163 / 156853809787392667$.

GÜL, Ç.; TOSUNOĞLU, M.; ERDOĞAN, D. Changes in the blood composition of some anurans. Acta Herpetologica, v. 6, n. 2, p. 137-147, 2011. doi: 10.13128/ Acta_Herpetol-9137.

HAMER, A. J.; MCDONNELL, M. J. Amphibian ecology and conservation in the urbanising world: a review. Biological Conservation, v. 141, n. 10, p. 2432-2449, 2008. doi: 10.1016/j.biocon.2008.07.020.

HEATLEY, J. J.; JOHNSON, M. Clinical technique: amphibian haematology: a practitioner's guide. Journal of Exotic Pet Medicine, v. 18, n. 1, p. 14-19, 2009. doi: 10.1053/j.jepm.2008.10.004.

KALOUSTIAN, K. V.; DULAC, R. W. Relationships between red blood cell indices and the effects of thyroxine in three species of amphibians. Comparative Biochemistry and Physiology Part A: Physiology, v. 73 , n. 3, p. 427-430, 1982. doi: 10.1016/03009629(82)90179-7. 
LAJMANOVÍCH, R. C.; PELTZER, P. P.; ATTADEMO, A. M.; CABAGNA-ZENKLUSEN, M.; JUNGES, C. M.; BASSO, A. AMPHIBIA, ANURA, Hylidae, Argenteohyla siemersi pederseni (Williams and Bosso, 1994): first record and some hematological data in Santa Fe Province, Argentina. Check List, v. 8, n. 4, p. 790-791, 2012.

MAHAPATRA, B. B.; DAS, M.; DUTTA, S. K.; MAHAPATRA, P. K. Hematology of Indian rhacophorid tree frog Polypedates maculatus Gray, 1833 (Anura: Rhacophoridae). Comparative Clinical Pathology, v. 21, n. 4, p. 453-460, 2012. doi: 10.1007/s00580-010-1118-y.

MITSURU, K. Relationships between number, size and shape of red blood cells in amphibians. Comparative Biochemistry and Physiology Part A: Physiology, v. 69, n. 4, p. 771-775, 1981. doi: 10.1016/0300-9629(81)90170-5.

NANO, R.; GRIFFINI, P.;BARNI, S. Morphohistochemical changes of the blood cells in the hibernating frog (Rana esculenta L.). Comparative Haematology International, v. 1, n. 4, p. 220-223, 1991. doi: 10.1007/BF00235375.

OMONONA, A. O.; EKPENKO, V. Haematology and prevalence of blood parasites of the common frog (Rana temporaria) in the tropical environment. Journal Veterinary Medicine and Animal Health, v. 3, n. 2, p. 14-20, 2011.

PONSEN, S.; NARKKONG, N. A.; PAMOK, S.; SAPPASO, K.; AENGWANICH, W. Hematological values and morphological observation of blood cells in balloon frog, Glyphogloossus molossus. Journal of Microscopy Society of Thailand, v. 22, p. 71-75, 2008.

POUNDS, J. A.; BUSTAMANTE, M. R.; COLOMA, L. A.; CONSUEGRA, J. A.; FOGDEN, M. P.; FOSTER, P. N.; LA MARCA, E.; MASTERS, K. L.; MERINO-VITERI, A.; PUSCHENDORF, R.; RON, S. R.; SÁNCHEZ-AZOFEIFA, G. A.; STILL, C. J.; YOUNG, B. E. Widespread amphibian extinctions from epidemic disease driven by global warming. Nature, v. 439, p. 161-167, 2006. doi: 10.1038/nature04246.

ROCHA, G. C.; FERREIRA, C. M.; TEIXEIRA, P. C.; DIAS, D. C.; FRANÇA, F. M.; ANTONUCCI, A. M.; MARCANTONIO, A. S.; LAURETTO, M. Physiological response of American bullfrog tadpoles to stressor conditions of capture and hypoxia. Pesquisa Veterinária
Brasileira, v. 30, n. 10, p. 891-896, 2010. doi: 10.1590/ S0100-736X2010001000014.

ROSENFELD, G. Corante pancrômico para hematologia e citologia clínica. Nova combinação dos componentes do May-Grünwald e do Giemsa num só corante de emprego rápido. Memórias do Instituto Butantan, v. 20, n. 1, p. $329-334,1947$.

RUSSELL, A. P.; BAUER, A. M.; JOHNSON, M. K. Migration in amphibians and reptiles: an overview of patterns and orientation mechanisms in relation to life history strategies. In: ELEWA, A. M. T. (Ed.) Migration of organisms: climate geography ecology. Berlin: Springer, 2005. p. 151-203.

SCHMID-SCHÖNBEIN, G. W.; SHIH, Y. Y.; CHIEN, S. Morphometry of human leukocytes. Blood, v. 56, n. 5, p. 866-875, 1980.

SEGAllA, M. V.; CARAMASCHI, U.; CRUZ, C. A. G.; GARCIA, P. C. A.; GRANT, T.; HADDAD, C. F. B.; LANGONE, J. Brazilian amphibians: list of species. Herpetologia Brasileira, v. 3, n. 2, p. 37-48, 2014.

SHUTLER, D.; MARCOGLIESE, D. J. Leukocyte profiles of northern leopard frogs, Lithobates pipiens, exposed to pesticides and hematozoa in agricultural wetlands. Copeia, v. 2011, n. 2, p. 301-307, 2011. doi: 10.1643/CP$10-065$.

SILVANO, D. L.; SEGALLA, M. V. Conservation of Brazilian amphibians. Conservation Biology, v. 19, n. 3, p. 653-658, 2005. doi: 10.1111/j.1523-1739.2005.00681.x.

SINSCH, U. Migration and orientation in anurans amphibians. Ethology Ecology and Evolution, v. 2, n. 1, p. $65-79,1990$. doi: 10.1080/08927014.1990.9525494.

STUART, S. N.; CHANSON, J. S.; COX, N. A.; YOUNG B. E.; RODRIGUES, A. S.; FISCHMAN, D. L.; WALLER, R. W. Status and trends of amphibian declines and extinctions worldwide. Science, v. 306, n. 5702, p. 1783-1786, 2004. doi: 10.1126/science.1103538.

TOZETTI, P. B.; LIMA, E. M.; NASCIMENTO, A. M.; ENDRINGER, D. C.; PINTO F. E.; ANDRADE, T. U.; 
MITTAG, A.; TARNOK, A.; LENZ, D. Morphometry to identify subtypes of leukocytes. Hematology/Oncology and Stem Cell Therapy, v. 7, n. 2, p. 69-75, 2014. doi: 10.1016/j.hemonc.2013.11.005.

WOJTASZEK, J.; ADAMOWICZ, A. Haematology of the fire-bellied toad, Bombina bombina L. Comparative Clinical Pathology, v. 12, n. 3, p. 129-134, 2003. doi: 10.1007/s00580-003-0482-2.

WRIGHT, K. M. Amphibiam husbandry and medicine. In: Mader, D. R. Reptile medicine and surgery. Philadelphia: WB Saunders. 1996. p. 436-458.
YOUNG, S.; WARNER, J.; SPEARE, R.; BERGER, L.; SKERRATT, L. F.; MULLER, R. Hematologic and plasma biochemical reference intervals for health monitoring of wild Australian tree frogs. Veterinary Clinical Pathology, v. 41, n. 4, p. 478-492, 2012. doi: 10.1111/j.1939165X.2012.00470.x.

ZHELEV, Z. M.; POPGEORGIEV, G. S.; ANGELOV, M. $\mathrm{V}$. Investigating the changes in the morphological content of the blood of Pelophylax ridibundus (Amphibia: Ranidae) as a result of anthropogenic pollution and its use as an environmental bioindicator. Acta Zoologica Bulgarica, v. 65, n. 2, p. 187-196, 2013. 